Publisher: LPPM STIE Muhammadiyah Bandung

E-ISSN: 2621-5306 P-ISSN: 2541-5255

Vol. 2 No. 3 September - Desember 2018

\title{
IMPLEMENTASI ANALISIS JABATAN DALAM PENEMPATAN \\ PEGAWAI DI BAGIAN KEPEGAWAIAN SEKRETARIAT DPRD KABUPATEN BANDUNG
}

\author{
Windry Setyaning Warsito \\ STIE Dharma Negara \\ windry.warsito09@gmail.com
}

\begin{abstract}
ABSTRAK
Organisasi dituntut untuk bersaing, tidak hanya mengenai aspek produktivitas, tetapi juga dalam hal kemudahan dan kenyamanan serta ketepatan waktu pelayanan yang diberikan.Organisasi merupakan wadah kegiatan dari orang-orang yang bekerjasama dalam usaha mencapai tujuan. Dalam wadah kegiatan itu setiap orang harus jelas tugas, wewenang, tanggung jawabnya, hubungan dan tata kerjanya, sehingga dapat tercapai tujuan organisasi

Dalam penelitian ini penulis menggunakan metode penelitian deskriptif. Data-data tersebut mula-mula diinventarisir kemudian disusun secara sistematis agar data tersebut dapat dijelaskan dan selanjutnya dianalisa berdasarkan teori yang ada.

Berdasarkan hasil jawaban responden terhadap variabel penempatan pegawai yang di dalamnya terdiri atas sub variabel prestasi kerja, pendidikan dan pengalaman maka dapat diperoleh jawaban responden secara keseluruhan rata-rata untuk variabel penempatan pegawai adalah 32,03 \% dengan katagori "kurang memuaskan" atau rendah
\end{abstract}

Kata Kunci : Analisis Jabatan dan Penempatan Pegawai

\section{ABSTRACT}

Organizations are required to compete, not only on aspects of productivity, but also in terms of ease and comfort as well as the timeliness of services provided. Organizations are a forum of activities from people who work together in an effort to achieve goals. In this activity, everyone must be clear about their duties, authority, responsibilities, relationships and work procedures, so that organizational goals can be achieve

In this study the author uses descriptive research method.. These data were first inventoried and then arranged systematically so that the data can be explained and then analyzed based on the existing theories.

Based on the results of respondents 'answers to the variable placement of employees in which consists of sub-variables of work performance, education and experience, the respondents' answers as a whole on average for the variable employee placement is $32.03 \%$ with the category "unsatisfactory" or low

Keywords: Job Analysis and Employee Placement 
Publisher: LPPM STIE Muhammadiyah Bandung

E-ISSN: 2621-5306 P-ISSN: 2541-5255

Vol. 2 No. 3 September - Desember 2018

\section{PENDAHULUAN}

Gejolak dan perubahan lingkungan dalam rangka globalisasi, perkembangan teknologi yang sangat pesat, perubahan demografi dan perubahan sosio-kultural, telah menyebabkan perubahan drastis dan mempengaruhi berbagai aspek kehidupan masyarakat di seluruh dunia. Tak terelakkan pula, gejolak dan perubahan itu akan mempengaruhi kemampuan suatu organisasi untuk berkompetisi dan mempertahankan kelangsungan hidupnya. Kemampuan itu akan sangat ditentukan oleh mutu sumber daya manusia yang dimiliki.Persaingan organisasi yang meningkat akan memaksakan organisasi untuk memperhatikan masalah sumber daya manusia di dalam strategi pengembangan organisasi (Dadang BI:3)

Organisasi dituntut untuk bersaing, tidak hanya mengenai aspek produktivitas, tetapi juga dalam hal kemudahan dan kenyamanan serta ketepatan waktu pelayanan yang diberikan.Organisasi merupakan wadah kegiatan dari orang-orang yang bekerjasama dalam usaha mencapai tujuan. Dalam wadah kegiatan itu setiap orang harus jelas tugas, wewenang, tanggung jawabnya, hubungan dan tata kerjanya, sehingga dapat tercapai tujuan organisasi (Dadang BI:3)

Untuk mencapai tujuannya suatu organisasi harus memiliki individu-individu dengan kualitas yang sesuai. Ini diwujudkan melalui aktivitas-aktivitas manajemen sumber daya manusia, yang secara ringkas dapat juga dikatakan sebagai upaya pendayagunaan Sumber Daya Manusia. (Dadang BI:4)

Pendayagunaan Sumber Daya Manusia di dalam oraganisasi antara lain dilakukan melalui fungsi-fungsi perencanaan sumber daya manusia, rekruitmen dan seleksi, penempatan sumber daya manusia, pengembangan sumber daya manusia, perencanan dan pengembangan karier, pemberian kompensasi, kesejahteraan, keselamatan, kesehatan kerja, hubungan industrial. Perencanaan dan implementasi fungsi-fungsi ini harus didukung pula oleh analisis jabatan yang baik dan proses penilaian unjuk kerja yang obyektif

(Dadang BI:4) 
Publisher: LPPM STIE Muhammadiyah Bandung

E-ISSN: 2621-5306 P-ISSN: 2541-5255

Vol. 2 No. 3 September - Desember 2018

Organisasi sangat memerlukan analisis jabatan dalam rangka mencapai tujuan organisasi, dimana analisis jabatan ini merupakan proses pengumpulan informasi tentang uraian pekerjaan dan persyaratan jabatan dalam melaksanakan pekerjaan, dalam rangka mewujudkan tujuan organisasi.Pegawai Negeri Sipil sebagai unsur aparatur negara sekaligus pelaksana penyelenggaraan administrasi umum dan administrasi pembangunan berfungsi sebagai motor penggerak jalannya pemerintahan yang kuat, efektif, efisien dan akuntabel (Dadang BI:3)

Pegawai Negeri Sipil yang diperlukan bukan hanya yang memiliki ketrampilan dan kemampuan profesionalis, melainkan juga diperlukan perubahan sikap mental dan yang memiliki etika dan moral yang tinggi serta dedikasi dan pengabdian kepada masyarakat.

Dalam melaksanakan tugas pekerjaan atau jabatan agar berjalan dengan baik, penempatan Pegawai Negeri Sipil perlu diperhatikan,Upaya yang dapat mendukung hal tersebut adalah dengan terlebih dahulu melakukan analisis jabatan dalam organisasi pemerintahan. Dengan analisis jabatan ini akan diperoleh informasi tentang segala sesuatu yang berkaitan dengan suatu jabatan. Informasi ini dapat dijadikan dasar yang kuat bagi pengambil keputusankeputusan yang berkaitan dengan Sumber Daya Manusia.

Dimana analisis jabatan ini akan dijadikan dasar dalam penempatan pegawai.Di Sekretariat DPRD Kab. Bandung analisis jabatan telah dilakukan akan tetapi belum dapat dilaksanakan secara optimal. Upaya yang telah dilakukan diantaranya telah adanya uraian pekerjaan atau jabatan dan persyaratan jabatan, akan tetapi hasil dari persyaratan jabatan belum dilaksanakan dalam penempatan pegawai, sehingga terjadi penempatan yang tidak sesuai dengan kebutuhan yang diperlukan organisasi.

Analisis jabatan merupakan produk kerja di Bagian Organisasi Sekretariat DPRD Kab.Bandung, yang dibuat dengan membentuk tim analisis yang melaksanakan analisis jabatan di Sekretariat DPRD Kab.Bandung, hasil analisis jabatan 
Publisher: LPPM STIE Muhammadiyah Bandung

E-ISSN: 2621-5306 P-ISSN: 2541-5255

Vol. 2 No. 3 September - Desember 2018

akan menghasilkan uraian pekerjaan atau jabatan dan persyaratan pekerjaan atau jabatan yang dapat digunakan dalam penempatan pegawai.

Analisis jabatan sangat berperan sekali dalam penempatan pegawai dimana dengan adanya analisis jabatan akan menghasilkan pegawai yang mampu bekerja efektif dan efisien dalam mencapai tujuan organisasi, sehingga sesuai dengan kebutuhan organisasi baik kualitas maupun kuantitas.Seseorang akan bekerja secara berdayaguna dan berhasil guna apabila mengetahui dengan jelas posisinya dalam suatu organisasi kerja.

Kejelasan itu sangat penting artinya bagi setiap pegawai karena memungkinkan mengetahui peranan dan sumbangan pekerjaan terhadap pencapaian tujuan kerja secara keseluruhannya.

Nawawi

(1999:129)

menyatakan : "Pegawai harus ditempatkan dengan posisi dan peranannya yang lebih jelas di dalam organisasi kerja, baik pegawai lama maupun pegawai baru yang diperoleh sebagai hasil seleksi““.
Dalam penempatan pegawai masih perlu diperhatikan persyaratan kesesuaian antara minat, bakat, pengetahuan, ketrampilan dan keahlian pegawai dengan jenis dan tingkat pekerjaan/jabatan yang dipercayakan kepadanya.Dengan kata lain penempatan harus berpegang kepada prinsip "The right man on the right place and the right man on the right job" yang artinya penempatan orang-orang yang tepat pada tempat dan untuk jabatan yang tepat. Dengan melakukan penempatan pegawai yang sesuai dengan prinsip tersebut $\mathrm{di}$ atas diharapkan akan meningkatkan kinerja pegawai sehingga tujuan organisasi dapat tercapai.

Dengan kata lain apabila sesuatu urusan diserahkan kepada yang bukan ahlinya maka tunggulah saat-saat kehancuran organisasi tersebut, sehingga diharapkan setiap Pengangkatan Pegawai Negeri Sipil di suatu organisasi untuk memegang suatu jabatan struktural harus mengikuti dan lulus pendidikan dan latihan kepemimpinan sesuai dengan kompetensi yang ditetapkan untuk jabatan tersebut. 
Publisher: LPPM STIE Muhammadiyah Bandung

E-ISSN: 2621-5306 P-ISSN: 2541-5255

Vol. 2 No. 3 September - Desember 2018

Tabel 1

Daftar Pegawai Berdasarkan Tingkat Pendidikan Di Sekretariat DPRD

\begin{tabular}{|c|c|c|c|c|c|}
\hline \multicolumn{6}{|c|}{ Kab.Bandung } \\
\hline $\mathrm{N}$ & Unit & Tingk & Pendi & $\mathrm{Ju}$ & $\mathrm{K}$ \\
\hline \multirow[t]{3}{*}{ o } & Kerja & at & dikan & mla & et \\
\hline & & Pendi & Sehar & & \\
\hline & & & usnya & & \\
\hline \multirow[t]{3}{*}{1} & Kabag & S1 IIP & $\mathrm{S} 1$ & 1 & \\
\hline & & TataPr & MSD & & \\
\hline & & aja & M & & \\
\hline \multirow[t]{3}{*}{2} & SubBag & S1 & S1 & 5 & \\
\hline & Umum & Huku & Adm & & \\
\hline & & $\mathrm{m}$ & Publik & & \\
\hline \multirow[t]{3}{*}{3} & Kasubag & S1 & S1 & 5 & \\
\hline & Umum & Psikol & Adm & & \\
\hline & & ogi & Publik & & \\
\hline \multirow[t]{3}{*}{4} & Pelaksana & S1 & S1 & 4 & \\
\hline & & Ekono & MSD & & \\
\hline & & $\mathrm{mi}$ & M & & \\
\hline \multirow[t]{3}{*}{5} & SubBag & SLTA & S1 & 2 & \\
\hline & Mutasi & & Adm & & \\
\hline & & & Publik & & \\
\hline \multirow[t]{4}{*}{6} & KaSubBa & $\mathrm{S} 1$ & S1 & 4 & \\
\hline & gMutasi & Adm & Adm & & \\
\hline & & Negar & Publik & & \\
\hline & & $\mathrm{a}$ & & & \\
\hline \multirow[t]{4}{*}{7} & Pelaksana & $\mathrm{S} 1$ & $\mathrm{~S} 1$ & 4 & \\
\hline & & Infor & MSD & & \\
\hline & & matik & $\mathrm{M}$ & & \\
\hline & & $\mathrm{a}$ & & & \\
\hline \multirow[t]{3}{*}{8} & SubBag & SLTA & S1 & 5 & \\
\hline & Diklat & & Adm & & \\
\hline & & & Publik & & \\
\hline 9 & $\begin{array}{c}\text { KaSubBa } \\
\text { gDiklat }\end{array}$ & SMK & SLTA & 1 & \\
\hline \multirow{3}{*}{$\begin{array}{l}1 \\
0 \\
\end{array}$} & Pelaksana & SLTA & & 5 & \\
\hline & & & & & \\
\hline & Jumlah & & & 36 & \\
\hline
\end{tabular}

Sumber : Bagian Umum Kepegawaian

Tabel 2

Rekapitulasi Kegiatan Pekerjaan Pegawai Yang Sering Terjadi Penundaan

Pekerjaan Keadaan Bulan September 2018

\begin{tabular}{|c|c|c|c|c|c|}
\hline $\begin{array}{l}\mathrm{N} \\
\mathrm{O}\end{array}$ & $\begin{array}{c}\text { Kegiat } \\
\text { an }\end{array}$ & $\begin{array}{l}\text { Us } \\
\text { ul }\end{array}$ & $\begin{array}{c}\text { Reali } \\
\text { sasi }\end{array}$ & $\begin{array}{l}\text { Terla } \\
\text { mbat }\end{array}$ & $\begin{array}{c}\text { Persen } \\
\text { tase }\end{array}$ \\
\hline 1 & $\begin{array}{c}\text { Pengur } \\
\text { usan } \\
\text { SK } \\
\text { Pensiu } \\
\text { n }\end{array}$ & 65 & 45 & 20 & $\begin{array}{c}30,77 \\
\%\end{array}$ \\
\hline 2 & $\begin{array}{c}\text { Pengur } \\
\text { usan } \\
\text { Huku } \\
\text { man }\end{array}$ & 30 & 20 & 10 & $\begin{array}{c}33,33 \\
\%\end{array}$ \\
\hline
\end{tabular}

\begin{tabular}{|c|c|c|c|c|c|}
\hline & $\begin{array}{c}\text { Disipli } \\
\mathrm{n}\end{array}$ & & & & \\
\hline 3 & $\begin{array}{c}\text { Pengur } \\
\text { usan } \\
\text { Kenaik } \\
\text { an } \\
\text { Pangka } \\
\text { t } \\
\text { Period } \\
\text { e } \\
\text { Oktobe } \\
\text { r 2009 }\end{array}$ & 5 & 190 & 15 & $7,32 \%$ \\
\hline 4 & $\begin{array}{c}\text { Pengur } \\
\text { usan } \\
\text { Karis }\end{array}$ & 55 & 35 & 20 & 36,36 \\
& & & & $\%$ \\
\hline 5 & Jumlah & 35 & 290 & 65 & 18,31 \\
& & & & \\
\hline
\end{tabular}

Sumber : Bagian Umum Kepegawaian

Berdasarkan pengamatan sementara penempatan pegawai di Bagian Kepegawaian Sekretariat DPRD Kab. Bandung masih belum memperhatikan prinsip tersebut, dikarenakan hasil analisis jabatan belum dilaksanakan dalam penempatan pegawai,apabila hasil analisis jabatan belum dilaksanakan secara efisien dan efektif hal tersebut akan membawa dampak negatif terhadap kinerja pegawai yang lain, serta kinerja organisasi pada Bagian Kepegawaian Sekretariat DPRD Kab. Bandung pada umumnya, dan tentu saja dalam hal ini tujuan organisasi yang telah ditetapkan akan sulit tercapai secara optimal dan kemampuan bersaing dan berdaya guna pegawai di dalam organisasi 
Publisher: LPPM STIE Muhammadiyah Bandung

E-ISSN: 2621-5306 P-ISSN: 2541-5255

Vol. 2 No. 3 September - Desember 2018

pada bagian kepegawaian Kab

Bandung akan turut menurun.

Dari uraian tersebut penulis menduga bahwa penempatan pegawai akan baik,apabila hasil analisis jabatan dapat dilaksanakan dengan optimal dalam penempatan pegawai sehingga dapat meningkatkan produktifitas kerja para Pegawai Negeri Sipil yang ditempatkan atau bertugas disetiap bagian dan instansi yag ada di Sekretariat DPRD Kab.Bandung.

\section{TINJAUAN LITERATUR DAN HIPOTESIS}

Dalam menghadapi perubahan yang terjadi dalam kehidupan masyarakat dituntut suatu organisasi yang dapat berkompetisi dan mempertahankan kelangsungan hidupnya. Kemampuan itu sangat ditentukan oleh mutu sumber daya manusia yang dimiliki, khususnya pegawai yang ada dalam organisasi tersebut, agar dapat meningkatkan kinerja dalam memberikan pelayanan kepada masyarakat.

Untuk meningkatkan kinerja pegawai dalam organisasi diperlukan informasi kepegawaian yang diperoleh dari analisis jabatan, yang akan digunakan dalam penempatan pegawai. Analisisis jabatan merupakan suatu proses yang memberikan informasi untuk menentukan tugas, kewajiban, tanggung jawab, kondisi kerja dan kualifikasi pegawai yang diperlukan untuk melakukan pekerjaanpekerjaan tertentu didalam sebuah organisasi.

Dari analisis jabatan akan diperoleh uraian pekerjaan dan persyaratan jabatan, dimana uraian jabatan merupakan pernyataan yang nyata dan teratur tentang tugas, tanggung jawab dan kondisi kerja dari suatu jabatan tertentu, sedangkan persyaratan jabatan menitikberatkan pada syarat-syarat mengenai orang yang diperlukan oleh jabatan, yang meliputi pendidikan, ketrampilan dan pengalaman.

Hal diatas jelas dinyatakan dinyatakan dalam :

1. Undang-Undang Nomor 43 Tahun 1999 tentang Perubahan atas UndangUndang Nomor 8 Tahun 1974 tentang Pokok-Pokok Kepegawaian. 
Publisher: LPPM STIE Muhammadiyah Bandung

E-ISSN: 2621-5306 P-ISSN: 2541-5255

Vol. 2 No. 3 September - Desember 2018

2. Peraturan Pemerintah No 13

Tahun 2002 tentang

Pengangkatan Pegawai

Negeri Sipil Dalam Jabatan

Struktural yang isinya bahwa:

"Pengangkatan Pegawai

Negeri Sipil dalam jabatan

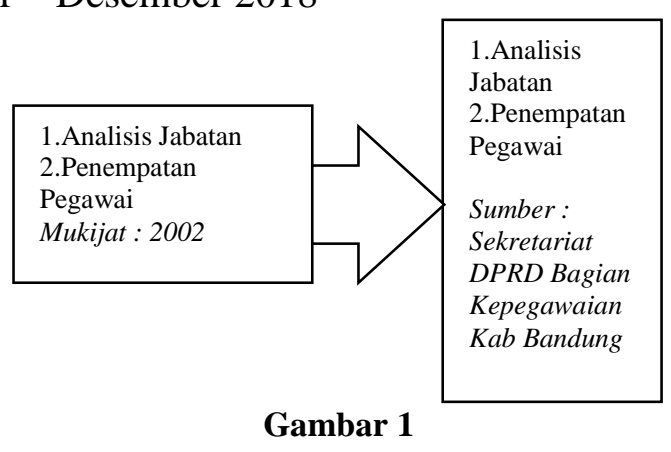

Paradigma Penelitian

\section{METODE PENELITIAN}

dan lulus pendidikan dan

latihan kepemimpinan sesuai

dengan kompetensi yang

ditetapkan untuk jabatan

tersebut".

3. Peraturan Pemerintah

Republik Indonesia Nomor

97 Tentang Formasi Pegawai Negri Sipil.

4. Peraturan Daerah Kota

BANDUNG Nomor 1 Tahun

2004 tentang Pembentukan

dan Susunan Organisasi

Perangkat Daerah Kota

Bandung

5. Peraturan Bupati

BANDUNGNomor 182

Tahun 2008 tentang Uraian

Tugas Pejabat Struktural Di

Lingkungan Sekretariat

Daerah, Sekretariat DPRD,

Kecamatan, dan Kelurahan

Kota Bandung.
Penelitian ini dilakukan di kantor Sekretariat Daerah Kab Bandung yang berkedudukan di Jl.Raya Soreang Kab Bandung dan penulis mengambil objek penelitian pegawai yang bekerja pada Sekretariat Daerah Kab. Bandung sedangkan unit analisisnya yaitu analisis jabatan dan penempatan pegawai

Penelitian ini memiliki variabel-variabel yang akan diteliti yang bersifat saling mempengaruhi. Dalam hal ini variabel-variabel ini dapat juga disebut sebagai objek penelitian. Variabel dapat diartikan sebagai sesuatu yang dijadikan objek penelitian sebagai faktor-faktor yang berperan dari peristiwa atau gejala yang akan diteliti. Moch Nazir (2005: 123) mengatakan bahwa variabel adalah konsep yang mempunyai bermacam-macam nilai. 
Publisher: LPPM STIE Muhammadiyah Bandung

E-ISSN: 2621-5306 P-ISSN: 2541-5255

Vol. 2 No. 3 September - Desember 2018

Menurut

Sugiyono,

(2008:20) mengemukakan bahwa variabel dapat didefinisikan sebagai atribut dari seseorang atau objek yang mempunyai variasi antara satu orang dengan yang lain atau satu objek dengan objek yang lain.

Sesuai dengan kedua pengertian di atas yang menjadi populasi dalam penelitian ini adalah manusia, yaitu Pegawai di Bagian Kepegawaian Sekretariat DAERAH Kab.Bandung. Dilihat dari segi jumlah populasi sebagai subyek yang jumlahnya hanya mencapai 36 (tiga puluh enam) orang maka populasi dalam hal ini adalah populasi terbatas.

Sesuai dengan pendapat tersebut, sampel dalam penelitian ini disebut dengan sampel total Dengan mengingat populasi dalam penelitian ini 32 orang maka teknik pengambilan sampel untuk dijadikan responden dalam penelitian ini menggunakan sampling jenuh atau sensus Hal ini sesuai dengan pendapat Sugiyono (2008:62) yang menyatakan bahwa : "Sampling jenuh adalah teknik penentuan sampel bila semua anggota populasi digunakan sebagai sampel. Hal ini sering dilakukan bila jumlah populasi relatif kecil, kurang dari 30 orang".

Analisis data hasil penelitian dilakukan melalui langkah-langkah sebagai berikut :

a.Persiapan.

b.Tabulasi.

c.Penerapan sesuai dengan pendekatan penelitian.

\section{HASIL DAN DISKUSI}

\section{Tanggapan Responden Tentang Analisis Jabatan}

Tabel 1

Uraian jabatan / pekerjaan yang ada pada saat ini dapat memberikan informasi /penjelasan mengenai apa yang harus saya kerjakan.

\begin{tabular}{|c|c|c|c|c|c|}
\hline Variabel & No.item & Skor & Jml & \% & Bobot \\
\hline Tugas & 1 & 5 & 6 & 18,75 & 30 \\
\hline & & 4 & 18 & 56,25 & 72 \\
\hline & & 3 & 4 & 12,50 & 12 \\
\hline & & 2 & 4 & 12,50 & 8 \\
\hline & & 1 & 0 & 0 & 0 \\
\hline Total & & & $\mathbf{3 2}$ & $\mathbf{1 0 0 \%}$ & $\mathbf{1 2 2}$ \\
\hline
\end{tabular}


Publisher: LPPM STIE Muhammadiyah Bandung

E-ISSN: 2621-5306 P-ISSN: 2541-5255

Vol. 2 No. 3 September - Desember 2018

Sumber : Data Olahan

Dari hasil tanggapan

responden atau $12,50 \%$ menyatakan responden tersebut yang tertera pada tabel di atas dapat diuraikan sebagai berikut sebanyak 6 responden atau $18,75 \%$ menyatakan sangat setuju, uraian jabatan/pekerjaan memberikan informasi/penjelasan kurang setuju dan tidak ada (0\%) responden yang menyatakan sangat tidak setuju ini berarti uraian tugas yang diberikan oleh atasan sudah memberikan penjelasan apa yang harus dikerjakan oleh bawahan mengenai apa yang harus dikerjakan pegawai di Bagian Sekretariat Daerah, 18 responden atau 56,25\% menyatakan setuju, 4 responden atau $15,50 \%$ menyatakan ragu-ragu, 4

Tabel 2

Pekerjaan yang saya hadapi secara jelas memberikan batasan kewajiban yang harus dilaksanakan

\begin{tabular}{|c|c|c|c|c|c|}
\hline Variabel & No.item & Skor & Jml & \% & Bobot \\
\hline Tugas & 1 & 5 & 2 & 6,25 & 10 \\
\hline & & 4 & 2 & 50 & 64 \\
\hline & & 3 & 8 & 25 & 24 \\
\hline & & 2 & 4 & 12,50 & 8 \\
\hline Total & & 1 & 2 & 6,25 & 2 \\
\hline & & & $\mathbf{3 2}$ & $\mathbf{1 0 0 \%}$ & $\mathbf{1 0 8}$ \\
\hline
\end{tabular}

Sumber : Data Olahan

Menurut tanggapan responden terhadap pernyataan pekerjaan yang dihadapi pegawai secara jelas memberikan batasan kewajiban yang harus dilaksanakan, 2 responden atau $6,25 \%$ menyatakan sangat setuju,16 responden atau 50\% menyatakan setuju, 8 responden atau
$25 \%$ menyatakan ragu-ragu, 4 responden atau $12,50 \%$ menyatakan kurang setuju dan 2 responden atau $12,5 \%$ menyatakan sangat tidak setuju, ini menandakan pekerjaan yang dihadapi oleh karyawan sudah jelas memberikan batasan untuk diikuti oleh karyawan

Tabel 3

Saya sering mendapat tugas yang tidak sesuai dgn uraian jabatan / pekerjaan karena ada perintah dari atasan 
Publisher: LPPM STIE Muhammadiyah Bandung

E-ISSN: 2621-5306 P-ISSN: 2541-5255

Vol. 2 No. 3 September - Desember 2018

\begin{tabular}{|c|c|c|c|c|c|}
\hline Variabel & No.item & Skor & Jml & \% & Bobot \\
\hline Tugas & 1 & 5 & 2 & 6,25 & 10 \\
\hline & & 4 & 2 & 6,25 & 8 \\
\hline & & 3 & 14 & 43,75 & 42 \\
\hline & & 2 & 10 & 31,25 & 20 \\
\hline & & 1 & 4 & 12,5 & 4 \\
\hline Total & & & $\mathbf{3 2}$ & $\mathbf{1 0 0 \%}$ & $\mathbf{8 4}$ \\
\hline
\end{tabular}

Sumber : Data Olahan

Tanggapan responden

terhadap peryataan pegawai sering mendapat tugas yang tidak sesuai dengan uraian jabatan/pekerjaan karena ada perintah dari atasan, ada 2 responden atau $6,25 \%$ menyatakan sangat tidak setuju, 2 responden atau
$6,25 \%$ menyatakan setuju, 14 responden atau $43,75 \%$ menyatakan kadang-kadang, 10 responden atau $31,25 \%$ menyatakan jarang sekali, 4 responden atau $12,50 \%$ menyatakan tidak pernah.

Tabel 4

Bobot Variabel Tugas $\left(\mathbf{X}_{\mathbf{1}}\right)$

\begin{tabular}{|c|c|c|c|}
\hline Variabel & Total Bobot & \% & Bobot \\
\hline Uraian jabatan & 122 & $39 \%$ & Baik \\
\hline Kejelasan Tugas & 108 & $34 \%$ & Cukup \\
\hline Kesesuaian Pekerjaan & 84 & $27 \%$ & Cukup \\
\hline Total & $\mathbf{3 1 4}$ & $\mathbf{1 0 0 \%}$ & \\
\hline Rata-rata & 105 & & Cukup \\
\hline
\end{tabular}

Sumber : hasil Penghitungan

Berdasarkan persentase ratarata tanggapan responden di atas, diketahui nilai atas tanggapan indikator terhadap uraian jabatan 122 atau $39 \%$, responden yang menjawab tugas cukup jelas ada $34 \%$ sedangkan kesesuaian pekerjaan dinilai oleh responden sebanyak $27 \%$
Bila dihubungkan dengan kriteria penilaian yang ditetapkan maka nilai rata-rata jawaban tertinggi dari alternatif tanggapan responden terhadap tugas adalah sebesar 105 atau 33\%. Nilai tersebut berada pada posisi nilai antara 83,3-108,9 atau dalam kategori cukup, hal ini mengandung arti bahwa sebagian besar responden beranggapan bahwa 
Publisher: LPPM STIE Muhammadiyah Bandung

E-ISSN: 2621-5306 P-ISSN: 2541-5255

Vol. 2 No. 3 September - Desember 2018

pemahaman akan tugas dirasakan cukup memuaskan sehingga ada penundaan dan penumpukan pekerjaan yang berakibat pelayanan yang diberikan menjadi kurang memuaskan sehingga diperlukan sosialisasi uraian pekerjaan terhadap pegawai agar dapat meningkatkan kinerja pegawai.

Berdasarkan hasil wawancara penulis terhadap Kabag dan Kasubbag pada bagian Kepegawaian Sekretariat Daerah Kab.Bandung dapat disimpulkan bahwa kurangnya pemahaman terhadap tugas dirasakan kurang memuaskan disebabkan pekerjaan yang diterima oleh pegawai tidak memberikan batasan kewajiban yang jelas.

Sedangkan menurut hasil observasi penulis kurangnya pemahaman terhadap tugas disebabkan jumlah pegawai yang sedikit dan beban kerja yang banyak, sehingga pegawai tidak memperhatikan tugas/pekerjaan yang harus dilaksanakannya, dan mereka hanya memperhatikan pekerjaan tersebut dapat diselesaikan.

Selain dari indikator tugas ada indikator lainnya yang termasuk variabel analisis jabatan yaitu indikator tanggung jawab, yang dapat dilihat pada tabel berikut ini

Tabel 5

Saya mengetahui kapan pekerjaan yang saya lakukan harus diselesaikan sesuai target / ketentuan

\begin{tabular}{|c|c|c|c|c|c|}
\hline Variabel & No.item & Skor & Jml & \% & Bobot \\
\hline Tanggung Jawab & 1 & 5 & 10 & 31,25 & 50 \\
\hline & & 4 & 16 & 50 & 64 \\
\hline & & 3 & 4 & 12,5 & 12 \\
\hline & & 2 & 2 & 6,25 & 4 \\
\hline & & 1 & 0 & 0 & 1 \\
\hline & & & $\mathbf{3 2}$ & $\mathbf{1 0 0 \%}$ & $\mathbf{1 3 1}$ \\
\hline
\end{tabular}

Sumber : Data Olahan

Dari hasil tanggapan responden seperti yang tertara pada tabel di atas daat diuraikan sebagai berikut :

Tanggapan responden terhadap pernyataan saya mengetahui kapan pekerjaan yang pegawai lakukan harus diselesaikan sesuai target/ketentuan terdapat 10 responden atau $31,25 \%$ menyatakan selalu, 16 responden atau 50\% menyatakan sering, 4 responden atau 
Publisher: LPPM STIE Muhammadiyah Bandung

E-ISSN: 2621-5306 P-ISSN: 2541-5255

Vol. 2 No. 3 September - Desember 2018

12,50\% menyatakan kadang-kadang, jarang sekali dan tidak ada (0\%)

2 responden atau $6,25 \%$ menyatakan responden menyatakan tidak pernah.

Tabel 6

Organisasi memberikan batasan tanggung jawab dalam mengambil suatu keputusan dalam melaksanakan tugas untuk mempermudah pekerjaan.

\begin{tabular}{|c|c|c|c|c|c|}
\hline Variabel & No.item & Skor & Jml & \% & Bobot \\
\hline Tanggung Jawab & 1 & 5 & 6 & 18,75 & 30 \\
\hline & & 4 & 8 & 25 & 32 \\
\hline & & 3 & 8 & 25 & 24 \\
\hline & & 2 & 2 & 6,25 & 4 \\
\hline & & 1 & 8 & 25 & 8 \\
\hline Total & & & $\mathbf{3 2}$ & $\mathbf{1 0 0 \%}$ & $\mathbf{9 8}$ \\
\hline
\end{tabular}

Sumber : Data Olahan

Berdasarkan tanggapan

responden terhadap pernyataan

organisasi memberikan batasan

tanggung jawab dalam mengambil

suatu keputusan dalam melaksanakan

tugas untuk mempermudah

pekerjaan, sebanyak 10 responden atau 31,25\% menyatakan selalu, 16 responden atau $50 \%$ menyatakan sering, 4 responden atau 12,5\% menyatakan kadang-kadang, 2 responden atau $6,25 \%$ menyatakan jarang sekali dan tidak ada responden yang menyatakan tidak pernah.

Tabel 7

Pekerjaan yang saya selesaikan mempunyai standar waktu penyelesaian pekerjaan

\begin{tabular}{|c|c|c|c|c|c|}
\hline Variabel & No.item & Skor & Jml & \% & Bobot \\
\hline Tanggung Jawab & 1 & 5 & 12 & 37,50 & 60 \\
\hline & & 4 & 8 & 25 & 32 \\
\hline & & 3 & 12 & 37,50 & 36 \\
\hline & & 2 & 0 & 0 & 0 \\
\hline Total & & 1 & 0 & 0 & 0 \\
\hline
\end{tabular}

Sumber : Data Olahan

Tanggapan responden

terhadap pernyataan pekerjaan yang harus pegawai selesaikan mempunyai standar waktu penyelesaian pekerjan. Ada 12 responden atau $37,50 \%$ menyatakan selalu, 8 responden atau $25 \%$ menyatakan sering, 12 responden atau $37,50 \%$ menyatakan kadangkadang dan tidak ada responden menyatakan jarang sekali atau tidak pernah. 
Publisher: LPPM STIE Muhammadiyah Bandung

E-ISSN: 2621-5306 P-ISSN: 2541-5255

Vol. 2 No. 3 September - Desember 2018

Tabel 8

Bobot Variabel Tanggung Jawab $\left(\mathrm{X}_{2}\right)$

\begin{tabular}{|c|c|c|c|}
\hline Variabel & Total Bobot & \% & Bobot \\
\hline Target Pekerjaan & 131 & $39 \%$ & Baik \\
\hline Batasan Tanggung Jawab & 98 & $34 \%$ & Cukup \\
\hline Standar waktu & 138 & $27 \%$ & Baik \\
\hline Total & $\mathbf{3 6 7}$ & $\mathbf{1 0 0 \%}$ & \\
\hline Rata-rata & 122 & $33 \%$ & Baik \\
\hline
\end{tabular}

Sumber : hasil Penghitungan

Berdasarkan persentase ratarata tanggapan responden di atas, diketahui nilai atas tanggapan terhadap indikator tanggung jawab terdapat $39 \%$ responden yang sudah mengetahui tentang target pekerjaannya, $34 \%$ responden menyatakan mengerti, akan batasan tanggung jawaban yang diberikan atasan $27 \%$ responden menyatakan standar waktu yang ditetapkan oleh perusahaan,Bila dihubungkan dengan kriteria penilaian yang ditetapkan maka nilai rata-rata tertinggi dari alternatif tanggapan responden terhadap tanggung jawab sebesar $33,33 \%$ berada pada posisi nilai antara 21\%-40\%, hal ini mengandung arti bahwa sebagian besar responden beranggapan bahwa pelaksanaan akan tanggung jawab dirasakan kurang memuaskan, sehingga menyebabkan adanya penundaan dan penumpukan pekerjaan yang berakibat pelayanan yang diberikan menjadi kurang memuaskan.

Berdasarkan hasil wawancara penulis kepada Kasubbag dapat disimpulkan penyebab kurangnya pelaksanaan tanggung jawab adalah pekerjaan yang diberikan dan disposisi atasan kurang memperhatikan batas waktu penyelesaiannya, sehingga pegawai melakukan pekerjaan dengan santai dan akan berakibat menimbulkan penumpukan pekerjaan.

Sedangkan menurut observasi penulis kurangnya pelaksanaan tanggung jawab disebabkan sistem garis kewenangan dan sistem otoritas dari atasan masih dirasakan dalam melaksanakan pekerjaan sehingga pegawai tidak merasa leluasa dalam melaksanakan pekerjaan, apalagi dalam mengambil suatu keputusan yang bersifat tehnis/operasinal sehingga pegawai tidak mempunyai prakarsa dalam melaksanakan tugas. 
Publisher: LPPM STIE Muhammadiyah Bandung

E-ISSN: 2621-5306 P-ISSN: 2541-5255

Vol. 2 No. 3 September - Desember 2018

Indikator ketiga dari analisis

dapat dilihat pada tabel berikut ini :

jabatan adalah kondisi kerja, yang

Tabel 9

Penataan ruangan kerja dan arsip yang ada sekarang telah memenuhi kondisi yang disyaratkan / ditentukan.

\begin{tabular}{|c|c|c|c|c|c|}
\hline Variabel & No.item & Skor & Jml & \% & Bobot \\
\hline Tanggung Jawab & 1 & 5 & 0 & 0 & 0 \\
\hline & & 4 & 8 & 25 & 32 \\
\hline & & 3 & 6 & 18,75 & 18 \\
\hline & & 2 & 14 & 43,75 & 28 \\
\hline & & 1 & 4 & 12,50 & 4 \\
\hline Total & & & $\mathbf{3 2}$ & $\mathbf{1 0 0 \%}$ & $\mathbf{8 2}$ \\
\hline
\end{tabular}

Sumber : Data Olahan

Dari hasil tanggapan responden tersebut yang tertera pada tabel di atas dapat diuraikan sebagai berikut

Tanggapan responden terhadap pernyataan penataan ruangan kerja dan arsip yang ada sekarang telah memenuhi kondisi yang disyaratkan/ditentukan, tidak ada responden $(0 \%)$ yang menyatakan sangat setuju, 8 responden atau $25 \%$ menyatakan setuju, 6 responden atau 18,75\% menyatakan cukup setuju, 14 responden atau $43,75 \%$ menyatakan kurang setuju dan 4 responden atau $12,50 \%$ menyatakan sangat tidak setuju.

Tabel 10

Fasilitas kerja yang ada, telah memenuhi persyaratan yang ditentukan untuk memenuhi kebutuhan kerja, sehingga dapat mengurangi beban kerja yang ada

\begin{tabular}{|c|c|c|c|c|c|}
\hline Variabel & No.item & Skor & Jml & \% & Bobot \\
\hline Tanggung Jawab & 1 & 5 & 4 & 12,50 & 20 \\
\hline & & 4 & 10 & 31,25 & 40 \\
\hline & & 3 & 6 & 18,75 & 18 \\
\hline & & 2 & 10 & 31,25 & 20 \\
\hline Total & & 1 & 1 & 6,25 & 1 \\
\hline
\end{tabular}

Sumber : Data Olahan

Dari hasil tanggapan responden tersebut yang tertera pada tabel di atas dapat diuraikan sebagai berikut : 
Publisher: LPPM STIE Muhammadiyah Bandung

E-ISSN: 2621-5306 P-ISSN: 2541-5255

Vol. 2 No. 3 September - Desember 2018

Sebanyak 4 responden atau $12,50 \%$ menyatakan sangat setuju dengan pernyataan fasilitas kerja yang ada telah memenuhi persyaratan yang ditentukan untuk memenuhi kebutuhan kerja, sehingga dapat mengurangi beban kerja yang ada, 10 responden atau $31,25 \%$ menyatakan setuju, 6 responden atau 18,75\% menyatakan cukup setuju, 10 responden atau $31,25 \%$ menyatakan kurang setuju, 1 responden atau $6,25 \%$ menyatakan sangat tidak setuju.

Tabel 11

Uraian jabatan / pekerjaan memberikan penjelasan kepada saya mengenai hubungan kerja, baik hubungan terhadap pimpinan, bawahan amaupun hubungan sesame staf

\begin{tabular}{|c|c|c|c|c|c|}
\hline Variabel & No.item & Skor & Jml & \% & Bobot \\
\hline Tanggung Jawab & 1 & 5 & 10 & 31,25 & 50 \\
\hline & & 4 & 18 & 56,25 & 72 \\
\hline & & 3 & 0 & 0 & 0 \\
\hline & & 2 & 4 & 12,50 & 8 \\
\hline & & 1 & 0 & 0 & 0 \\
\hline Total & & & $\mathbf{3 2}$ & $\mathbf{1 0 0 \%}$ & $\mathbf{8 0}$ \\
\hline
\end{tabular}

Sumber : Data Olahan

Dari hasil tanggapan responden tersebut yang tertera pada tabel di atas dapat diuraikan sebagai berikut :

\section{Menurut} tanggapan responden terhadap pernyataan uraian jabatan/pekerjaan memberikan penjelasan kepada pegawai mengenai hubungan kerja, baik hubungan terhadap pimpinan, bawahan maupun hubungan sesama staf, ada 10 responden atau $31,25 \%$ menyatakan sangat setuju, 18 responden atau $56,25 \%$ menyatakan setuju, tidak ada (0\%) responden menyatakan cukup setuju, 4 responden atau 12,50\% menyatakan kurang setuju, dan tidak ada (0\%) responden menyatakan sangat tidak setuju.

Berdasarkan persentase ratarata jawaban responden di atas, diketahui nilai atas tanggapan terhadap indikator kondisi kerja, $14,58 \%$ responden menyatakan sangat mendukung, $\quad 37,50 \%$ responden menyatakan mendukung, $12,50 \%$ responden menyatakan cukup mendukung, 29,17\% responden menyatakan kurang mendukung dan $6,25 \%$ responden menyatakan sangat tidak mendukung.

Bila dihubungkan dengan kriteria penilaian yang ditetapkan 
Publisher: LPPM STIE Muhammadiyah Bandung

E-ISSN: 2621-5306 P-ISSN: 2541-5255

Vol. 2 No. 3 September - Desember 2018

maka nilai rata-rata jawaban tertinggi

dari alternatif tanggapan responden terhadap kondisi kerja adalah sebesar $37,50 \%$. Nilai tersebut mempunyai arti bahwa indikator kondisi kerja berada pada kriteria penilaian kurang memuaskan,karena berada pada posisi nilai antara $21 \%-40 \%$, hal ini mengandung arti bahwa sebagian besar responden beranggapan bahwa kondisi kerja yang ada di instansi pada saat ini dirasakan kurang mendukung, sehingga adanya penundaan dan penumpukan pekerjaan yang berakibat pelayanan yang diberikan menjadi kurang memuaskan.

\section{Penempatan Pegawai}

Untuk meningkatkan kinerja pegawai dalam penempatan pegawai

Tabel 12

Prestasi kerja yang saya miliki dapat mendukung saya dalam melaksanakan pekerjaan

\begin{tabular}{|c|c|c|c|c|c|}
\hline Variabel & No.item & Skor & Jml & \% & Bobot \\
\hline Prestasi Kerja & 1 & 5 & 8 & 25 & 50 \\
\hline & & 4 & 8 & 25 & 26 \\
\hline & & 3 & 14 & 43,75 & 12 \\
\hline & & 2 & 0 & 0 & 4 \\
\hline Total & & 1 & 2 & 6,25 & 2 \\
\hline
\end{tabular}

Sumber : Data Olahan

Dari hasil tanggapan responden tersebut yang tertera pada tabel di atas dapat diuraikan sebagai berikut : hendaknya berdasarkan pada prinsip "The right man on the right place", dimana menempatkan seseorang pegawai pada tempat yang tepat. Agar dalam penempatan pegawai tidak mengalami kesalahan, terlebih dahulu diperlukan analisis jabatan dalam hal penempatan pegawai, sehingga akan diperoleh pegawai yang sesuai dengan kebutuhan yang diperlukan.

Tanggapan responden tentang penempatan pegawai pada Bagian Kepegawaian Sekretariat Daerah Kab.Bandung dalam hal ini dilihat dari prestasi kerja, pendidikan dan pengalaman yang akan penulis sajikan pada tabel-tabel di bawah ini 
Publisher: LPPM STIE Muhammadiyah Bandung

E-ISSN: 2621-5306 P-ISSN: 2541-5255

Vol. 2 No. 3 September - Desember 2018

pekerjaan, diperoleh jawaban menyatakan cukup, tidak ada (0\%) sebanyak 8 responden atau $25 \%$ responden menyatakan kurang menyatakan sangat setuju, 8 setuju, dan 2 responden atau 6,25\% responden atau $25 \%$ menyatakan menyatakan sangat tidak setuju. setuju, 14 responden atau $43,75 \%$

Tabel 13

Saya belum optimal menghasilkan prestasi kerja, sehubungan dengan kurang mendukungnya pendidikan / ketrampilan saya

\begin{tabular}{|c|c|c|c|c|c|}
\hline Variabel & No.item & Skor & Jml & \% & Bobot \\
\hline Prestasi Kerja & 1 & 5 & 6 & 18,75 & 50 \\
\hline & & 4 & 2 & 6,25 & 26 \\
\hline & & 3 & 14 & 43,75 & 12 \\
\hline & & 2 & 8 & 25 & 4 \\
\hline Total & & 1 & 2 & 6,25 & 2 \\
\hline
\end{tabular}

Sumber : Data Olahan

Tanggapan 4 responden atau kemudian 4 responden atau $12,50 \%$ $12,59 \%$ menyatakan sangat setuju, menyatakan setuju, 10 responden belum optimalnya pegawai atau $31,25 \%$ menyatakan kadangmenghasilkan prestasi kerja, kadang, 10 responden atau $31,25 \%$ sehubungan dengan kurang menyatakan kurang setuju, 4 mendukungnya responden atau $12,50 \%$ menyatakan pendidikan/ketrampilan pegawai, tidak setuju sekali.

Tabel 14

Penilaian prestasi kerja yang dicapai telah sesuai dengan hasil kerja dan digunakan sebagai dasar dalam penempatanpegawai

\begin{tabular}{|c|c|c|c|c|c|}
\hline Variabel & No.item & Skor & Jml & \% & Bobot \\
\hline Prestasi Kerja & 1 & 5 & 10 & 31,25 & 50 \\
\hline & & 4 & 14 & 43,75 & 26 \\
\hline & & 3 & 4 & 12,50 & 12 \\
\hline & & 2 & 2 & 6,25 & 4 \\
\hline & & 1 & 2 & 6,25 & 2 \\
\hline Total & & & $\mathbf{3 2}$ & $\mathbf{1 0 0 \%}$ & $\mathbf{9 4}$ \\
\hline
\end{tabular}

Sumber : Data Olahan

Tanggapan responden sesuai dengan hasil kerja 14 terhadap pernyataan penilaian digunakan sabagai dasar dalam prestasi kerja yang dicapai telah penempatan pegawai, ada 6 
Publisher: LPPM STIE Muhammadiyah Bandung

E-ISSN: 2621-5306 P-ISSN: 2541-5255

Vol. 2 No. 3 September - Desember 2018

responden atau $18,75 \%$ menyatakan selalu, 2 responden atau $6,25 \%$ menyatakan sering, 14 responden atau 43,75\% menyatakan kadang-kadang, 8 responden atau $25 \%$ menyatakan jarang sekali, 2 responden atau 6,25 $\%$ menyatakan tidak pernah.

Berdasarkan persentase ratarata tanggapan responden di atas, diketahui nilai atas tanggapan terhadap indikator prestasi kerja, ada $18,75 \%$ responden menyatakan sangat diperlukan, $14,58 \%$ responden menyatakan diperlukan, $39,58 \%$ responden menyatakan cukup diperlukan, $18,75 \%$ responden menyatakan kurang diperlukan dan $8,33 \%$ responden menyatakan sangat tidak diperlukan.

\section{Berdasarkan}

kriteria penilaian yang ditetapkan maka nilai rata-rata jawaban alternatif tertinggi yang di dapat dari tanggapan responden adalah sebesar $39,58 \%$ yang berarti pernyataan tersebut berada pada katagori "Kurang Memuaskan“, karena nilainya berada pada posisi nilai $21 \%-40 \%$, hal itu mengandung arti bahwa sebagian besar responden menyatakan bahwa prestasi kerja pegawai pada Sekretariat Daerah Kab.Bandung yang pada saat ini kurang diperhatikan dalam hal penempatan pegawai.

Sesuai dengan hasil wawancara yang penulis lakukan dapat disimpulkan bahwa prestasi kerja kurang diperhatikan dalam penempatan pegawai disebabkan belum adanya sistem penempatan yang didasarkan pada prestasi kerja, karena alat penilaian prestasi kerja yang berbentuk DP3 tidak relevan untuk megukur prestasi kerja pegawai.

Sedang dari hasil observasi penulis ditemukan penempatan pegawai masih berorientasi terhadap alumni suatu perguruan tinggi yang dominan, sehingga pegawai yang lain tidak dapat berkembang, apalagi menduduki suatu jabatan, hal ini dapat dilihat pada tabel di bawah ini.

Tabel 15

Jumlah Pegawai Berdasarkan Alumni

Lulusan

Keadaan : Oktober 2017

\begin{tabular}{|c|c|c|c|c|}
\hline No & Jabatan & Alumni & Jumlah & $\begin{array}{c}\text { Ket } \\
\text { Lulus }\end{array}$ \\
\hline 1 & Kabag & APDN & 1 & 1999 \\
\hline 2 & $\begin{array}{l}\text { Kasubag } \\
\text { Umum }\end{array}$ & STMN & 3 & 1990 \\
\hline 3 & Staf & $\begin{array}{c}\text { S1 } \\
\text { UNIKA }\end{array}$ & 8 & 2001 \\
\hline 4 & $\begin{array}{c}\text { Kasubag } \\
\text { Mutasi }\end{array}$ & SLTA & 3 & 1989 \\
\hline 5 & Staf & SMK & 8 & 2003 \\
\hline 6 & $\begin{array}{c}\text { Kasubbag } \\
\text { Diklat }\end{array}$ & $\begin{array}{l}\text { STIA } \\
\text { LAN }\end{array}$ & 3 & 1987 \\
\hline 7 & Staf & SLTA & 8 & 1988 \\
\hline
\end{tabular}


Publisher: LPPM STIE Muhammadiyah Bandung

E-ISSN: 2621-5306 P-ISSN: 2541-5255

Vol. 2 No. 3 September - Desember 2018

Dari data di atas terdapat 1 orang dari lulusan APDN/STPDN, 8 orang lulusan S1 IIP, 8 orang lulusan UNIKA, 3 orang lulusan STIA LAN, 3 orang lulusan STM Bandung, 8 orang lulusan SMK Bandung, dan 11 orang lulusan SLTA Bandung.

Tabel 16

Pendidikan yang saya miliki memenuhi persyaratan jabatan / pekerjaan yang telah ditentukan, sehingga memudahkan saya dalam memberikan pelayanan dengan baik

\begin{tabular}{|c|c|c|c|c|c|}
\hline Variabel & No.item & Skor & Jml & \% & Bobot \\
\hline Pendidikan & 1 & 5 & 4 & 12,50 & 50 \\
\hline & & 4 & 10 & 31,25 & 26 \\
\hline & & 3 & 8 & 25 & 12 \\
\hline & & 2 & 10 & 31,25 & 4 \\
\hline Total & & 1 & 0 & 0 & 2 \\
\hline
\end{tabular}

Sumber : Data Olahan

Dari hasil tanggapan responden pada tabel di atas, dapat diuraikan sebagai berikut

Tanggapan responden terhadap pernyataan pendidikan yang pegawai miliki memenuhi persyaratan jabatan/pekerjaan yang telah ditentukan, sehingga memudahkan saya dalam memberikan pelayanan

Tabel 17

Latar belakang pendidikan saya dapat di aplikasikan di dalam pekerjaan yang saya emban

\begin{tabular}{|c|c|c|c|c|c|}
\hline Variabel & No.item & Skor & Jml & \% & Bobot \\
\hline Pendidikan & 1 & 5 & 4 & 12,50 & 50 \\
\hline & & 4 & 12 & 31,25 & 26 \\
\hline & & 3 & 12 & 25 & 12 \\
\hline & & 2 & 2 & 31,25 & 4 \\
\hline & & 1 & 2 & 0 & 2 \\
\hline
\end{tabular}


Publisher: LPPM STIE Muhammadiyah Bandung

E-ISSN: 2621-5306 P-ISSN: 2541-5255

Vol. 2 No. 3 September - Desember 2018

\begin{tabular}{|c|c|c|c|c|c|}
\hline Total & & & 32 & $100 \%$ & 94 \\
\hline
\end{tabular}

Sumber : Data Olahan

Sebanyak 4 responden atau $12,50 \%$ menyatakan sangat setuju latar belakang pendidikan dapat diaplikasikan di dalam pekerjaan, 12 responden atau $37,50 \%$ menyatakan setuju, 12 responden atau 37,50\% menyatakan cukup setuju, 2 responden atau $6,25 \%$ menyatakan kurang setuju dan 2 responden atau $6,25 \%$ menyatakan tidak setuju sekali.

Tabel 18

Dalam Penempatan Pegawai Latar Belakang Pendidikan Sangat diPerhatikan

\begin{tabular}{|c|c|c|c|c|c|}
\hline Variabel & No.item & Skor & Jml & \% & Bobot \\
\hline Pendidikan & 1 & 5 & 8 & 12,50 & 50 \\
\hline & & 4 & 16 & 31,25 & 26 \\
\hline & & 3 & 4 & 25 & 12 \\
\hline & & 2 & 2 & 31,25 & 4 \\
\hline & & 1 & 2 & 0 & 2 \\
\hline Total & & & $\mathbf{3 2}$ & $\mathbf{1 0 0 \%}$ & $\mathbf{9 4}$ \\
\hline
\end{tabular}

Sumber : Data Olahan

Menurut tanggapan responden terhadap pernyataan dalam penempatan pegawai latar belakang pendidikan sangat diperlukan, ada 8 responden atau $25 \%$ menyatakan sangat setuju, 16 responden atau 50\% menyatakan setuju, 4 responden atau $12,50 \%$ menyatakan cukup setuju, 2 responden atau $6,25 \%$ menyatakan kurang setuju, 2 responden atau $6,25 \%$ menyatakan tidak setuju sekali.
Berdasarkan persentase ratarata tanggapan responden di atas, diketahui nilai atas tanggapan terhadap indikator pendidikan ada $16,67 \%$ responden menyatakan sangat diperlukan, 39,50\% responden menyatakan diperlukan, $25 \%$ responden menyatakan cukup diperlukan, $14,58 \%$ responden menyatakan kurang diperlukan, $4,17 \%$ responden menyatakan tidak diperlukan sekali.

Jika dilihat berdasarkan kriteria penilaian yang ditetapkan, 
Publisher: LPPM STIE Muhammadiyah Bandung

E-ISSN: 2621-5306 P-ISSN: 2541-5255

Vol. 2 No. 3 September - Desember 2018

maka nilai rata-rata jawaban alternatif tertinggi yang didapat dari tanggapan responden adalah 39,58 $\%$. Berarti pendidikan berada pada posisi nilai antara $21 \%-40 \%$, hal ini mengandung arti bahwa sebagian besar responden dan beranggapan bahwa pendidikan pegawai kurang diperhatikan dalam hal penempatan pegawai pada Sekretariat Daerah Kab.Bandung.

Berdasarkan wawancara penulis dapat disimpulkan dalam penempatan pegawai kurang memperhatikan pendidikan hal ini disebabkan penempatan pegawai berdasarkan sistem senioritas dan

like in dislike.Sedangkan dari hasil observasi penulis ditemukan dalam penempatan pegawai kurang memperhatikan pendidikan disebabkan Baperjakat kurang mampu/propesional dalam melakukan analisis jabatan sehingga dalam penempatan pegawai kualifikasi pendidikan tidak diperhatikan, hal ini dapat dilihat pada tabel 1.1

Indikator ketiga yang diangkat dalam skripsi mengenai penempatan pegawai adalah pengalaman pegawai yang dapat dilihat pada tabel di bawah ini.

Tabel 19

Pekerjaan yang saya lakukan memerlukan pengalaman agar dapat menunjang pelaksanaan pekerjaan saya

\begin{tabular}{|c|c|c|c|c|c|}
\hline Variabel & No.item & Skor & Jml & \% & Bobot \\
\hline Pengalaman & 1 & 5 & 8 & 12,50 & 50 \\
\hline & & 4 & 12 & 31,25 & 26 \\
\hline & & 3 & 6 & 25 & 12 \\
\hline & & 2 & 4 & 31,25 & 4 \\
\hline Total & & 1 & 2 & 0 & 2 \\
\hline
\end{tabular}

Sumber : Data Olahan

Dari hasil tanggapan responden terhadap pengalaman kerja seperti yang terlihat pada tabel $4.23 \mathrm{di}$ atas dapat diuraikan sebagai berikut :

Tanggapan responden terhadap pernyataan pekerjaan yang pegawai lakukan memerlukan pengalaman agar dapat menunjang pelaksanaan pekerjaan, ada 8 responden atau $25 \%$ menyatakan sangat setuju, 12 responden atau $37,50 \%$ menyatakan setuju, 6 
Publisher: LPPM STIE Muhammadiyah Bandung

E-ISSN: 2621-5306 P-ISSN: 2541-5255

Vol. 2 No. 3 September - Desember 2018

responden atau $18,75 \%$ menyatakan

dan 2 responden atau $6,25 \%$

cukup setuju, 4 responden atau

menyatakan tidak setuju sekali.

$12,50 \%$ menyatakan kurang setuju

Tabel 20

Pengalaman kerja di instansi saya selalu dijadikan dasar di dalam penempatan pegawai

\begin{tabular}{|c|c|c|c|c|c|}
\hline Variabel & No.item & Skor & Jml & \% & Bobot \\
\hline Pengalaman & 1 & 5 & 0 & 25 & 50 \\
\hline & & 4 & 12 & 75 & 26 \\
\hline & & 3 & 14 & 62,5 & 12 \\
\hline & & 2 & 4 & 25 & 4 \\
\hline & & 1 & 2 & 12,50 & 2 \\
\hline Total & & & $\mathbf{3 2}$ & $\mathbf{1 0 0 \%}$ & $\mathbf{9 4}$ \\
\hline
\end{tabular}

Sumber : Data Olahan

Menurut tanggapan responden terhadap pernyataan pengalaman kerja di instansi selalu dijadikan dasar di dalam penempatan pegawai, tidak ada $(0 \%)$ responden yang menyatakan sangat setuju, 12 responden atau $37,50 \%$ menyatakan setuju, 14 responden atau 43,75\% manyatakan cukup setuju, 4 responden atau $12,50 \%$ menyatakan kurang setuju, 2 responden atau $6,25 \%$ menyatakan tidak setuju sekali.

Berdasarkan persentase ratarata jawaban responden di atas, diketahui nilai atas tanggapan terhadap indikator pengalaman kerja, ada $12,50 \%$ responden manyatakan sangat diperlukan, $37,50 \%$ responden menyatakan diperlukan, $31,25 \%$ responden menyatakan cukup diperlukan, $12,50 \%$ responden menyatakan kurang diperlukan dan $6,25 \%$ responden menyatakan tidak diperlukan sekali.

Bila dihubungkan dengan kriteria penilaian yang ditetapkan, maka nilai rata-rata jawaban alternatif tertinggi yang didapat dari tanggapan responden adalah 37,50\% yang berarti "Kurang Memuaskan" sebagian besar responden beranggapan bahwa pengalaman kerja dalam penempatan pegawai kurang diperhatikan.

Berdasarkan hasil wawancara penulis dapat disimpulkan bahwa dalam penempatan pegawai kurang memperhatikan pengalaman kerja hal ini disebabkan penempatan pegawai 
Publisher: LPPM STIE Muhammadiyah Bandung

E-ISSN: 2621-5306 P-ISSN: 2541-5255

Vol. 2 No. 3 September - Desember 2018

yang tidak sesuai dengan

pengalaman kerja terdahulunya yang pegawai miliki, sehingga pegawai memerlukan waktu untuk adaptasi terhadap pekerjaan.

Sedangkan dari hasil observasi penulis ditemukan penempatan pegawai kurang memperhatikan pengalaman disebabkan sering terjadi mutasi pada bagian kepegawaian hal ini dapat dilihat pada tabel di bawah ini.

Tabel 21

Keadaan Pegawai Berdasarkan Masa

Kerja Pada Bagian Kepegawaian

Keadaan : September 2018

\begin{tabular}{|c|c|c|c|c|}
\hline $\begin{array}{c}\text { N } \\
\text { o }\end{array}$ & Jabatan & $\begin{array}{c}\text { Masa } \\
\text { Kerja }\end{array}$ & $\begin{array}{c}\text { Jumla } \\
\text { h }\end{array}$ & $\begin{array}{c}\text { Ket } \\
\text { Lulu } \\
\text { s }\end{array}$ \\
\hline 1 & Kabag & $\begin{array}{c}2 \\
\text { Bulan }\end{array}$ & 1 & $\begin{array}{c}199 \\
9\end{array}$ \\
\hline 2 & $\begin{array}{c}\text { Kasuba } \\
\text { g } \\
\text { Umum }\end{array}$ & $\begin{array}{c}4 \\
\text { Bulan }\end{array}$ & 3 & $\begin{array}{c}199 \\
0\end{array}$ \\
\hline 3 & Staf & $\begin{array}{c}\text { 1Tah } \\
\text { un 1 } \\
\text { Bulan }\end{array}$ & 4 & 200 \\
& 1 & 1 & 198 \\
& $\begin{array}{c}\text { Kasuba } \\
\text { g } \\
\text { Mutasi }\end{array}$ & $\begin{array}{c}\text { Tahun } \\
\text { Bulan }\end{array}$ & & 9 \\
\hline 5 & Staf & 8 & 8 & 200 \\
& & Bulan & & 3 \\
\hline 6 & Kasubb & 6 & 1 & 198 \\
\hline
\end{tabular}

\begin{tabular}{|c|c|c|c|c|}
\hline & ag & Tahun & & 7 \\
Diklat & 2 & & \\
\hline 7 & Staf & 2 & 4 & 198 \\
& & $\begin{array}{c}\text { Tahun } \\
2\end{array}$ & & 8 \\
& & Bulan & & \\
\hline 8 & Kabag & 1 & 1 & 199 \\
& Mutasi & $\begin{array}{c}\text { Tahun } \\
3\end{array}$ & & 9 \\
& & $\begin{array}{c}3 \\
\text { Bulan }\end{array}$ & & \\
\hline 9 & Staf & 1 & 3 & 199 \\
& & $\begin{array}{c}\text { Tahun } \\
10\end{array}$ & & 0 \\
& & Bulan & & \\
\hline 10 & Staf & 5 & 3 & 200 \\
& & $\begin{array}{c}\text { Tahun } \\
9\end{array}$ & & 1 \\
& & $\begin{array}{l} \\
\text { Bulan }\end{array}$ & & \\
\hline 11 & Staf & 6 & 3 & 198 \\
& & Bulan & & 9 \\
\hline
\end{tabular}

Sumber : data olahan

Dari data di atas masa kerja pegawai dibagian kepegawaian rata rata di bawah 2 tahunan, hanya 2 orang pegawai yang memiliki masa kerja 5 tahun keatas dan dianggap senior dibagian tersebut, sedangkan yang lainnya masih baru. Untuk memudahkan dalam memahami dan membaca data-data di atas disini penulis buatkan rekapitulasi data tersebut sebagai berikut :

Tabel 22

Rekapitulasi Tanggapan Responden Terhadap Variabel Analisis Jabatan ( $\mathbf{N}=32$ )

\begin{tabular}{|c|l|c|c|c|c|c|c|}
\hline No. & \multicolumn{1}{|c|}{ Pertanyaan } & $\begin{array}{c}\text { Sangat } \\
\text { Setuju }\end{array}$ & Setuju & $\begin{array}{c}\text { Ragu- } \\
\text { ragu }\end{array}$ & $\begin{array}{c}\text { Tidak } \\
\text { Setuju }\end{array}$ & $\begin{array}{c}\text { Sangat } \\
\text { Tidak } \\
\text { Setuju }\end{array}$ & f \\
\hline 1 & Tugas & 10 & 36 & 26 & 18 & 6 & 96 \\
\hline
\end{tabular}


Publisher: LPPM STIE Muhammadiyah Bandung

E-ISSN: 2621-5306 P-ISSN: 2541-5255

Vol. 2 No. 3 September - Desember 2018

\begin{tabular}{|c|l|c|c|c|c|c|c|}
\hline & Total \% & 31,25 & 112,50 & 81,25 & 56,25 & 18,75 & 300 \\
\hline 2 & TanggungJawab & 28 & 32 & 24 & 4 & 8 & 96 \\
\hline & & 87,50 & 100 & 75 & 12,50 & 25 & 300 \\
\hline 3 & Kondisi kerja & 14 & 36 & 12 & 28 & 6 & 96 \\
\hline & & 43,75 & 112,50 & 37,50 & 87,50 & 18,75 & 300 \\
\hline 4 & Kualifikasi Pegawai & 24 & 48 & 12 & 4 & 8 & 96 \\
\hline & & 75 & 150 & 37,50 & 12,50 & 25 & 300 \\
\hline & & 76 & 152 & 74 & 54 & 28 & 384 \\
\hline & \% Rara-rata jawaban & 19,79 & 39,58 & 19,27 & 14,06 & 7,29 & 100 \\
\hline
\end{tabular}

Sumber : data olahan

Dari tabel di atas dapat dinyatakan bahwa variabel analisis jabatan yang terdiri dari indikator : Tugas, Tanggung jawab, Kondisi kerja dan Kualifikasi Pegawai, pada saat ini belum digunakan dalam penempatan pegawai di Bagian Kepegawaian Sekretariat Daerah Kab.Bandung, hal ini bisa dilihat dari hasil tanggapan responden yang yang menjawab sebanyak 39,58\%, yang apabila dikaitkan dengan kriteria penilaian, yang ditetapkan dalam penelitian ini, nilai presentase terletak pada nilai 21\%-40\% dalam katagori "Kurang Memuaskan“.Adapun akibat dari belum digunakan hasil analisis jabatan dalam penempatan pegawai masih ditemukan :

1.Hampir sebagian pegawai masih belum memahami akan tugas dan tanggung jawabnya dalam melaksanakan pekerjaan.

2.Kondisi kerja belum mendukung dalam pelaksanaan kerja baik tata ruang dan peralatan kerja yang digunakan.

3.Dalam penempatan pegawai belum memperhatikan kualifikasi pegawai yang dibutuhkan.

Tabel 22

Rekapitulasi Tanggapan Responden Terhadap Variabel Penempatan Pegawai Pada Sekretariat Daerah Kota Bandung ( $N=32$ )

\begin{tabular}{|c|l|c|c|c|c|c|c|}
\hline No. & \multicolumn{1}{|c|}{ Pertanyaan } & $\begin{array}{c}\text { Sangat } \\
\text { Setuju }\end{array}$ & Setuju & $\begin{array}{c}\text { Ragu- } \\
\text { ragu }\end{array}$ & $\begin{array}{c}\text { Tidak } \\
\text { Setuju }\end{array}$ & $\begin{array}{c}\text { Sangat } \\
\text { Tidak } \\
\text { Setuju }\end{array}$ & f \\
\hline 1 & Prestasi kerja & 18 & 14 & 38 & 18 & 8 & 96 \\
\hline & Total \% & 56,25 & 43,75 & 118,75 & 56,25 & 25 & 300 \\
\hline 2 & Pendidikan & 16 & 38 & 24 & 14 & 4 & 96 \\
\hline
\end{tabular}


Publisher: LPPM STIE Muhammadiyah Bandung

E-ISSN: 2621-5306 P-ISSN: 2541-5255

Vol. 2 No. 3 September - Desember 2018

\begin{tabular}{|c|l|c|c|c|c|c|c|}
\hline & & 50 & 118,75 & 75 & 43,75 & 12,50 & 300 \\
\hline 3 & Pengalaman Kerja & 8 & 24 & 20 & 8 & 4 & 64 \\
\hline & & 25 & 75 & 62,50 & 25 & 12,50 & 200 \\
\hline & & 42 & 76 & 82 & 40 & 16 & 256 \\
\hline & & 131,25 & 237,50 & 256,25 & 125 & 50 & 800 \\
\hline
\end{tabular}

Sumber : data olahan

Demikian juga dengan hasil tanggapan responden terhadap variabel penempatan pegawai, penilaian yang diberikan oleh responden terhadap variabel penempatan pegawai adalah $32,03 \%$. Berdasarkan prestasi kerja, pendidikan dan pengalaman pegawai yag pada saat ini, maka dapat dinyatakan bahwa penempatan pegawai saat ini masih rendah, hal ini bisa dilihat pada hasil tanggapan responden dengan nilai tertinggi yang sebesar $32,03 \%$ yang apabila dikaitkan dengan katagori penilaian dan nilai persentase terletak pada nilai $21 \%-40 \%$ dengan katagori "Kurang Memuaskan".

Dalam penempatan pegawai ditemukan masih rendahnya unsur prestasi kerja, pendidikan dan pengalaman digunakan untuk dasar penempatan, hal ini dapat dilihat dari masih ditemukannya :

1.Penempatan pegawai masih mengacu pada sistem senioritas.
2.Dalam penempatan pegawai masih ditemukan penempatan pegawai yang tidak sesuai dengan pendidikan hal ini dapat dilihat dalam tabel 1.1.

3.Sering terjadinya mutasi dalam bagian kepegawaian, hal ini dapat dilihat dari tabel 4.20, dimana masa kerja pegawai di bagian kepegawaian rata-rata masih di bawah 2 tahun.

\section{b.. Faktor-Faktor Penghambat Analisis Terhadap Analisis Jabatan Dalam Penempatan Pegawai di Sekretariat Daerah Kab. Bandung}

Menurut Informasi yang diperoleh melalui wawancara dan observasi ternyata faktor-faktor penghambat yang paling dirasakan dalam upaya penempatan pegawai adalah sebagai berikut :

a.Penempatan pegawai masih mengacu pada sistem senioritas, dan tidak didasarkan pada hasil analisis jabatan sehingga pegawai 
Publisher: LPPM STIE Muhammadiyah Bandung

E-ISSN: 2621-5306 P-ISSN: 2541-5255

Vol. 2 No. 3 September - Desember 2018

yang berprestasi kurang diberikan

kesempatan untuk maju dan menduduki jabatan, hal tersebut berakibat pada menurunnya motivasi pegawai yang berprestasi dalam bekerja yang dapat menurunkan kinerja pegawai sehingga tujuan organisasi tidak tercapai.

Dalam sistem senioritas ini penempatan pegawai hanya berdasarkan pada pangkat/golongan ruang dan lamanya masa kerja, tanpa memperhatikan prestasi kerja pegawai, dengan sistem ini tidak didasarkan kepada kompetensi yang dimiliki pegawai sebagaimana tercantum didalam spesifikasi pekerjaan sehingga penempatan pegawai tidak sesuai dengan pekerjaan/tugas.

b.Sumber Daya Manusia yang dibutuhkan kurang memenuhi persyaratan yang diperlukan oleh organisasi, dan tidak didasarkan pada hasil analisis jabatan sehingga penempatan didasarkan pada pertimbangan alumni suatu perguruan tinggi yang dominan serta like and dislike.
Dengan melakukan penempatan seperti ini diharapkan akan menghasilkan jalinan kerja sama dalam melaksanakan pekerjaan agar tercapainya tujuan organisasi, tapi sebaliknya terjadi adanya pembentukkan blok-blok pegawai dalam melaksanakan pekerjaan.

Penempatan dengan sistem ini akan menghambat karir pegawai yang berprestasi, sehingga melemahkan motivasi pegawai dalam melaksanakan pekerjaan yang dikerjakannya.

c.Lemahnya sistem informasi pegawai yang berakiabat sulitnya mencari data data/informasi pegawai pendukung dalam penempatan pegawai, sehingga informasi pegawai yang diperlukan kurang lengkap dalam menempatkan seorang pegawai.

Sistem informasi yang digunakan sementara berdasarkan DUK yang ada, tanpa memperhatikan prestasi pegawai dalam melaksanakan pekerjaan.

c. Upaya Yang Dilakukan Dalam Penempatan Pegawai Pada Bagian Kepegawaian Sekretariat Daerah Kab. Bandung 
Publisher: LPPM STIE Muhammadiyah Bandung

E-ISSN: 2621-5306 P-ISSN: 2541-5255

Vol. 2 No. 3 September - Desember 2018

Adanya hambatan seperti yang terungkap di atas, hendaknya perlu ditanggapi dengan serius oleh pihak manajemen dalam organisasi Sekretariat Daerah Kab. Bandung terutama dalam hal analisis jabatan, karena dengan melakukan analisis terhadap analisis jabatan dalam penempatan pegawai akan diperoleh pegawai yang berkualitas sehingga dapat meningkatkan kinerja organisasi.

Berdasarkan hasil wawancara kepada Kabag dan Kasubbag terdapat beberapa upaya yang telah dilakukan Bagian Kepegawaian Sekretariat Daerah Kab. Bandung dalam hal penempatan pegawai yaitu

1.Dalam penempatan pegawai sudah mulai memperhatikan kompetensi pegawai agar memudahkan dalam melaksanakan pekerjaan, kompetensi itu baru memperhatikan kemampuan yang dimiliki pegawai sehingga dianggap ia dapat melaksanakan pekerjaan dan mampu beradaptasi dengan cepat dalam melaksanakan pekerjaan.

2.Memberikan kesempatan pada pegawai lain yang memenuhi persyaratan pekerjaan/jabatan untuk melaksanakan pekerjaan, serta mengurangi sistem kebijakan pimpinan yang didasarkan pada like and dislike, sehingga akan berakibat pada menurunyanya motivasi pegawai dalam melaksanakan pekerjaan.

3.Melakukan pengarsipan yang teratur dan sistematis sehingga lebih memudahkan didalam mencari dan mendapatkan datadata yang diperlukan yang menyangkut pegawai dalam proses penempatan.

Dengan adanya data tersebut diharapkan dapat menunjang dalam hal penempatan pegawai, sehingga indentitas pegawai tersebut dapat diketahui baik yang menyangkut karir, hukuman disiplin dan lain-lain.

\section{V.Simpulan}

Setelah dilakukan pembahasan mengenai masalah analisis jabatan yang diperoleh melalui penelitian, dapat disimpulkan sebagai berikut :

a. Analisis jabatan telah dilaksanakan, akan tetapi hasil dari analisis jabatan belum dilaksanakan secara 
Publisher: LPPM STIE Muhammadiyah Bandung

E-ISSN: 2621-5306 P-ISSN: 2541-5255

Vol. 2 No. 3 September - Desember 2018

optimal dalam penempatan

e. Faktor-faktor penghambat

pegawai di Bagian

dalam penempatan pegawai di

Kepegawaian Sekretariat

Bagian

Kepegawaian

Daerah Kab.Bandung, hal ini

Sekretariat Daerah Kab.

dapat dilihat dari kriteria

penilaian tentang analisis

jabatan dalam penampatan

pegawai yang masih rendah.

b. Berkaitan analisis jabatan

meliputi: tugas, tanggung

jawab, kondisi kerja dan

kualifikasi pegawai, secara

keseluruhaan rata-rata

sebesar 39,58\% dengan

katagori "kurang

memuaskan“, secara jelas

berikut ini akan diuraikan

rata-rata jawaban responden

untuk masing-masing

indikator tersebut.

Bandung ntara lain adalah

sebagai berikut :

a. Penempatan pegawai masih mengacu pada sistem senioritas, sehingga pegawai yang berprestasi tidak diberikan kesempatan untuk maju dan menduduki jabatan.

b. Sumber daya manusia yang dibutuhkan kurang memenuhi persyaratan yang diperlukan oleh organisasi, sehingga penempatan didasarkan pada pertimbangan alumni suatu perguruan tinggi yang dominan serta like and dislike.

c. Berdasarkan hasil jawaban responden terhadap variabel penempatan pegawai yang di dalamnya terdiri atas sub variabel prestasi kerja, pendidikan dan pengalaman maka dapat diperoleh jawaban responden secara keseluruhan rata-rata untuk variabel penempatan pegawai adalah

c. Kurangnya data-data informasi pegawai pendukung dalam penempatan pegawai, sehingga informasi pegawai yang diperlukan kurang lengkap dalam menempatkan seorang pegawai.

\section{DAFTAR PUSTAKA}

Flippo, Edwin.B 1976, Principles of personnel Management, Tokyo: MC.Graw-hill Kagakusha 
Publisher: LPPM STIE Muhammadiyah Bandung

E-ISSN: 2621-5306 P-ISSN: 2541-5255

Vol. 2 No. 3 September - Desember 2018

Malayu.Hasibuan 2004, Manajemen

Sumber Daya Manusia dan

Kunci Keberhasilan, Jakarta:

Haji Masagung

Marwansyah dan Mukaram 2000,

Manajemen Sumber Daya

Manusia, Bandung: Poltek

Negeri Bandung

Mitrani, Alain, et.all 1995

Manajemen Sumber Daya

Manusia Berdasarkan

Kompetensi,Jakarta:

Interenasa

Mathis, Robert.L and Jackson, John 2001,Manajemen Sumber

Daya Manusia, terjemahan Jimmy Sadell dan Bayu Prawira Hie, Jakarta: Selemba Empat

Moekijat 2002, Manajemen Kepegawaian, Bandung: Mandar Maju

Muhadjir, Noeng 1996, Metode Penelitian Kualitatif, Yogyakarta: Rake Sarasia.

Munthe, Dame 1993 Analisis Jabatan dalam Praktek, Bandung: Mandar Maju

Musanef 1996, Manajemen Kepegawaian di Indonesia, Jakarta: PT.Toko Gunung Agung

Nazir, Moh 1998, Metode Penelitian, Jakarta: Ghalia Indonesia

Nawawi, Hadari 1992, Administrasi Personalia untuk Meningkatkan Produktifitas Kerja, Jakarta: Haji Masagung

Siagian, Sondang.P 1996, Manajemen Sumber Daya Manusia, Jakarta: PT. Bumi Aksara

Simamora,Henry 2001, Manajemen Sumber Daya Manusia,Yogyakarta: STIE YKPN

Singarimbun, Masri 1989, Metode Penelitian Survey, Jakarta: LP3ES
Siswanto, Bedjo 1990, Organisasi Kepemimpinan dan Prilaku Administrasi, Jakarta: Haji Masagung

Sugiyono 2008, Metode Penelitian Adminstrasi, Bandung: Elpabeta

Suharsimi Arikunto .1998. Prosedur Penelitian suatu Pendekatan Praktek, Jakarta : Bina Aksara

Surakhmad,W 1991, Pengantar Penelitian Ilmiah, Bandung: Tersito

Sutisnawijaya, Tjahyo 1999, Riset dan Praktek Penelitian Administrasi, Bandung: Limlit Unpas Press

Tayibnapis, Burhannudin 1995, Administrasi Kepegawaian, Jakarta: PT Pradnya Paramita

T.Hani Handoko 1994, Manajemen Personalia dan Sumber daya Manusia, Yogyakarta: BPFE

The Liang Gie 1974, Administrasi Perkantoran Moderen, Yogyakarta: Nurcahaya

Wandy Implementasi Analisis Jabatan Dalam Penempatan Pegawai Di Bagian Kepegawaian Dinas Pertanian

Werther,William and Davis,Keith 1982, Personel Management and human Resources, Tokyo: MC.Graw Hill Kogokusha

Wursanto, IG 1997, Manajemen Kepegawaian 1, Yogyakarta: Kanisius

Yoder, Dale 1962, Personal: The Management of People at Work, New York: Mc Millan Publishing co

Undang-Undang Nomor 43 Tahun 1999 tentang Perubahan atas Undang-Undang Nomor 8 
Publisher: LPPM STIE Muhammadiyah Bandung

E-ISSN: 2621-5306 P-ISSN: 2541-5255

Vol. 2 No. 3 September - Desember 2018

Tahun 1974 tentang Pokok-

Pokok Kepegawaian

Keputusan Badan Kepegawaian

Negara Nomor 43/KEP/2001

tentang Standar Kompetensi

Jabatan Struktural Pegawai

Negeri Sipil

Peraturan Daerah Kota

BANDUNGNomor 1 Tahun

2004 tentang Pembentukan

dan Susunan Organisasi

Perangkat Daerah Kota

Bandung

Peraturan Walikota

BANDUNGNomor $\quad 182$

Tahun 2005 tentang Uraian

Tugas Pejabat Struktural Di

Lingkunagan Sekretariat

Daerah, Sekretariat

DAERAH, Kecamatan dan

Kelurahan Kota Bandung 